\title{
Okullarda Örgütsel Dedikodu İle Bağlılık Arasındaki İlişkinin Öğretmen Görüşlerine Göre İncelenmesi ${ }^{1}$
}

\author{
Hamza ALAKAŞLI ${ }^{2}$ Rasim TÖSTEN ${ }^{3}$
}

Gönderim Tarihi: 05.02 .2022

Kabul Tarihi: 08.03.2022

Yayın Tarihi: 19.04 .2022

Öz: Bu araştırmada, öğretmenlerin örgütsel dedikodu ve örgütsel bağlllığa ilişkin görüşleri incelenmiştir. Örgütsel dedikodu; en az iki kişi arasında ortamda bulunmayan kişiler hakkındaki olumlu veya olumsuz değerlendirici konuşmalar; örgütsel bağlllık ise çalışanların örgütün amaçlarına bağlı kalarak örgütte kalmaya devam etmesi ve işine, örgüte duyduğu iyi duyguları yansıtarak çalışması şeklinde tanımlanabilir. Bu araştırmanın amacı öğretmenlerin örgütsel dedikodunun işlevine ilişkin görüşleri ile örgütsel bağlllık düzeyleri arasındaki ilişkilerinin incelenmesidir. Bu araştırma nicel yöntemli olup ilişkisel tarama modelinde desenlenmiştir. Araştırmanın evrenini, Siirt ilinde görev yapan okul öncesi, ilkokul, ortaokul ve lise öğretmenleri, örneklemini ise belirtilen okul kademelerinde görev yapan 384 öğretmen oluşturmaktadır. Araştırmanın verileri, Han ve Dağlı (2018) tarafından geliştirilen "Örgütsel Dedikodu Ölçeği" ile Dağlı, Elçiçek ve Han (2018) tarafından uyarlanan "Örgütsel Bağlllık Ölçĕği" kullanılarak elde edilmiştir. Elde edilen sonuçlara göre, öğretmenlerin örgütsel dedikodunun haberdar olma işlevine yönelik görüşleri ile bağlllıkları arasında negatif yönde, düşük düzeyde, anlamlı bir ilişkiye rastlanmıştır. Okuldaki örgütsel dedikodunun, öğretmenlerin örgütsel bağllılı düzeyinin anlamlı bir yordayıcısı olduğu saptanmıştır. Örgütsel dedikodunun zararlı işlevleri arttıkça öğretmenlerin bağlılıkları azalmaktadır.

Anahtar Kelimeler: İnformal İletişim, Öğretmen, Okul, Örgütsel Dedikodu, Örgütsel Bağlllık.

\section{Examination of the Relationship Between Organizational Gossip and Commitment in Schools According to Teacher Views}

\begin{abstract}
In this study, teachers ' views on organizational gossip and organizational commitment were examined. Organizational gossip can be defined as positive or negative evaluative conversations between at least two people about those who are not in the environment; organizational commitment can be defined as employees continuing to stay in the organization, adhering to the goals of the organization, and working decisively to reflect their good feelings for their work; and the organization. The aim of this research is to examine the relationship between teachers ' views on the functions of organizational gossip and their level of organizational commitment. This research is quantitative research patterned as a relational survey model. The population of the study consists of preschool, primary, secondary and high school teachers working in Siirt province, and the sample is 384 teachers working at the specified school levels. The data was obtained by using the "Organizational Gossip Scale" developed by Han and Dağ 1 ( 2018) and the "Organizational Commitment Scale" adapted by Dağll, Elçiçek and Han (2018). According to the results, a negative, low-level, significant relationship was found between teachers ' views on the function of having information of organizational gossip and their commitment. It has been found that organizational gossip in school is a significant predictor of the level of organizational commitment of teachers. As the harmful functions of organizational gossip increase, teachers- ' commitment decreases.
\end{abstract}

Keywords: Informal Communication, Teacher, School, Organizational Gossip, Organizational Commitment.

\section{Gíriş}

Bireyler, yaşamlarını sürdükleri her süreçte kişisel, sosyal, ekonomik gibi her türlü ihtiyaca sahiptirler ve var oldukları günden beridir çevreleriyle uyum içerisinde yetenekleri doğrultusunda bu ihtiyaçlarını giderme yolundadırlar. Kişiler, belirtilen ihtiyaçların bazılarını kendi başlarına karşılayabiliyorken bazılarının karşılanmasında başka bireylerin yeteneklerine ihtiyaç duyarlar.

\footnotetext{
1 Bu çalışma 2021 yılında Doç. Dr. Rasim TÖSTEN danışmanlığında yürütülmüş olan Yüksek Lisans Tezinden üretilmiştir.

2 Öğretmen, Siirt MEM, alakaslihamza@gmail.com, ORCID: 0000-0003-2675-6298

${ }^{3}$ Siirt Üniversitesi, Eğitim Fakültesi, Türkiye, rasimtosten@siirt.edu.tr, ORCID: 0000-0001-5135-7286
} 
Bu kişiler, ihtiyaçların karşılanması için bazen bireylerle bazen de farklı gruplarla işbirliği yapmak zorunda kalırlar. Özellikle modernleşen dünyada ihtiyaçların çeşitlenmesiyle beraber iş birliğinin önemi artmıştır. İşte bu çeşitlenen ihtiyaçlarının giderilmesi amacıyla örgütlere daha çok ihtiyaç duyulmuştur. Örgütler belli bir amaç uğruna bir araya gelen bireylerden meydana gelir. Örgüt, belirlenmiş hedefler istikametinde bireylerin gayretlerinin koordine edildiği bir yönetim fonksiyonudur (Güçlü, 2003: 147). Aynı zamanda örgüt alt bölümlere ayrılmış eylemleri içeren bir kurumun devamlılığını, devam ettirilmesi gereken yapıyı ifade eder (Ergeneli, 2006). Bir başka deyişle, bireylerin bir anlaşma sunmaları ve bu anlaşmaların ortak hedef ve amaçlar barındırmasıdır (Ergen, 2015: 21). Bu kapsamda ihtiyaçlar dâhilinde örgütler; siyasal, askeri, kültürel, ekonomik, eğitim, vb. amaçlarla kurulabilir. Kurulan örgütler içinde eğitim örgütleri toplumsal dinamikler için vazgeçilmezdirler.

İnsanoğlu var olduğu günden itibaren çevresiyle etkileşim içindedir. Etkileşim sürecinde ise araç olarak iletişim kullanılmaktadır (Karasu, 2020: 1). İletişim genel olarak kişilerin duygu ve düşüncelerini veya bildiklerini farklı araçlar kullanarak başkalarına iletmesi şeklinde ifade edilebilir (TDK, 2020). Aynı zamanda iletişim insanların kendi düşüncelerini aktarabilmeleri adına birincil bir kazanımdır (Erol ve Akyüz, 2015: 150). Kişiler arasındaki duygu ve düşüncelerin ortak hale gelme sürecidir (Memişoğlu, 2013: 140). İletişim çoğunlukla sınırları belirlenmiş olan formal (resmi, planlı) iletişim ve sınırları tam olarak belirlenemeyen informal (gayri resmi, plansız) iletişim olarak gerçekleşir. Formal iletişim hiyerarşik yapısı belli olan örgütlerde; resmi yazı, toplantı, sunum, konferans vb. şekillerde ast-üst ilişkileri gözetilerek yapılırken informal iletişim dedikodu ve söylenti yoluyla hiyerarşik yapı gözetilmeksizin yapılır (Han, 2019).

İnformal iletişim türü olarak ele alınan dedikodu; başkaları hakkında yapılan şahsi ve mahrem konuşmalar (Kardaş, 2019: 7), kişilerin kendi görüşlerini rastgele bir kümeye yayma çabası (Leblebici, Yıldız ve Karasoy, 2009: 563-564), iki bireyin orada olmayan üçüncü bireye ilişkin görüşmeleri (Artaç, 2017: 25), ortamda bulunmayan bir kişi hakkında yapılan olumlu ve olumsuz konuşmalar (Tekgöz, 2013: 4) olarak tanımlanmaktadır. Aynı zamanda dedikodu; bireylerin çevresinde yaşayan herkes hakkında birtakım verilerle donatılmasını sağlamaktır (Bekteş, 2018: 73). Dedikodu resmi iletişime göre daha hızlı, kişileri eğlendiren ve kendiliğinden gelişen bir iletişim yoludur (Usta, Kaya ve Özyurt, 2018: 5). Dedikodu ilkel toplumlarda adaleti kuran en eski iletişim aracıdır (Eroğlu, 2005: 205). Bir başka deyişle dedikodu insanlık tarihinde kullanılan en temel haberleşme yönetimidir (Erol ve Akyüz, 2015: 151). Dedikodu idari anlamda sağladiğı çıkarlarla beraber kurumun işleyişini bozabilen önlenemez bir iletişim kanalıdır (Akduru ve Semerciöz, 2017: 106). Dedikodu hayatın her alanında karşımıza çıkan bireyleri olumlu ve olumsuz yönde etkileyebilen bir kavramdır (Gürbüz, 2019: 1).

Birey dedikoduyla ilk olarak ailesiyle veya yakın çevresiyle tanışmış olabilir. Bu dedikodular kişiler, gruplar veya örgütler hakkında yapılan değerlendirici konuşmalar olabilir. Belli bir yaşa geldikten sonra ise ister grupta tanınabilirlik ve konum elde etme isteği, isterse de sevilmeyen veya gruptan dışlanmak istenen kişiler hakkındaki konuşmalar yani dedikodular devam edebilir. Bununla beraber birey meslek sahibi olarak herhangi bir örgüte girdiğinde meslektaşlarının örgütte yaşadığı tayin, kariyer, maaş vb. olaylar hakkında veya örgütün yapısı, amaçları ve işleyişi gibi durumlar karşısında yine dedikoduyu kullanabilir.

Dedikodu anlamı itibariyle pek çok kültürde kötü bir alg1 yaratmaktadır. Yaratılan alg1 bu kavramın belki de yöneticilerin gözünden kaçmasına ve bu nedenle dedikodunun örgüt üzerindeki etkisinin incelenmesinin göz ardı edilmesine neden olmuş olabilir. Dedikodu örgütlerde ulaşılması zor olan bazı bilgilere ulaşma kolaylığı sağlar (Danış, 2015: 82). Bu kolaylıkla 
beraber örgüt içindeki bazı kişiler aynı düzeyde oldukları arkadaşlarını etkilemek adına o düzeyde kişilerin bilmesinin imkânı olmadığı bazı bilgileri bildiğini ileri sürüp dedikodu yoluyla arkadaşlarını etkileyerek örgütteki sosyal statüsünü artırma yoluna girebilir. Eylemi gerçekleştiren kişi eylemden etkilenen kişiyle ilgili bilgilere sahipken bu bilgileri kendi yorumuyla birleştirebilir. Bundan dolayı dedikodu yapan kişiler bu eylemden etkilenen (hakkında dedikodu yapılan) kişi hakkındaki izlenimini de yorumlarına katarak eylemi gerçekleştirebilir. Bunun yanında dedikodu yapan kişiler eylemden etkilenen kişi hakkında bilgi aktarımında bulunurken kendi yorumlarını da kattığının farkındadır. Bu eylemden etkilenen kişi hakkındaki sırlarını ifşa ettiğinden eylemde bulunan kişiler arasındaki sosyal ilişki gelişebilir.

Birey yaşamının her anında dedikoduyla karşılaşabilir. Bazen hakkında dedikodu yapılan kişi kendisi olurken bazen de dedikodu üreten veya dedikoduyu yayan role bürünerek dedikoduyu devam ettirebilir. Aile veya yakın çevrede, içinde bulunulan grup veya örgütlerde yapılan dedikodular gelecekte de karşılaşılabilen hususlardan biri olmaya devam edebilir.

Ahlaki değerlerin eksik kalması dedikoduyu ortaya çıkaran etmenlerden biridir (Bacaksız ve Yıldırım, 2013: 118). İnsanlar yaptıkları dedikoduların her ne kadar etik dışı olduğunu bilseler de bazen bundan kendilerini alıkoyamamaktadırlar. Dedikodu yapmanın olumlu bir davranış olmadığını bile bile insanların bunu yapmaya devam etmesi aynı zamanda dedikodunun sosyal ilişkileri geliştirmesi, bilinmeyen konular hakkında bilgi sunma aracı olarak görev yapması ve dedikodu yapan kişilerin dedikodu yaparken eğlenmesi gibi olumlu tarafları da dedikodu kavramının karmaşık bir yapıdan oluşmasından dolayıdır. Dedikodunun karmaşık yapısı dedikodu oluşumuna neden olan faktörler incelenerek anlaşılabilir. Bu faktörler; örgüt üyelerinde görülen bazı olumsuz tutum ve duygular, örgüt üyelerinin gerekli konulardaki bilgi eksiklikleri ve örgüt üyeleri arasındaki formal iletişimden kaynaklanan eksiklikler diye sıralanabilir (Han, 2019: 77). Dedikodular ortaya çıktıktan sonra örgütlerde birtakım işlevleri olur. Bunlar genel olarak; haberdar olma: Bireyin dedikodular sayesinde örgütteki olaylar, tarihler, isimler ve maaşlar hakkında bilgi sahibi olması ( Bilginoğlu ve Yozgat, 2020: 2593), sosyal ilişkileri geliştirme: Bireyin deneyim ve tecrübelerini aktarması için oluşturduğu ortamlarda, grup üyesinin duygu ve düşüncelerini açıllamasında, mutluluk duymasında ve böylelikle üyeler arasında etkileşimi artırması (Gürbüz, 2019: 12-13) ve örgütsel zarar: Resmi iletişim kanallarının yetersiz olduğu durumlarda örgüt yöneticilerinin iletişim becerilerini zararlı bir şekilde etkilemesiyle iletişim boşluğu yaratarak örgüt kültürüne, iklimine ve havasına zarar vermesi (Bektaş ve Erdem, 2015: 131-132) şeklinde açılanabilir.

Örgütsel dedikodunun yoğun olduğu veya düşük olduğu okullarda örgüt üyelerinin örgüte karş1 tutumları değişir. Bu tutumlardan biri de bağlılıktır. Dedikodu örgüt içerisinde istendik şekilde yönlendirildiği takdirde bireylerin örgütsel bağlılığının arttığı yapılan alanyazın araştırmasında göze çarpmıştır (Solmaz, 2004: 567, Usta vd., 2018: 8, Kapferer, 1992). Örgütsel bağlılığın örgüt üyeliğini sürdürmek için bir zorunluluk, bir istek veya ihtiyaçtan doğabilir (Allen ve Mayer, 1990). Örgütsel bağlılık sadık olma, örgütün belirlediği hedeflere inanma ve bireyin örgüte duyduğu içten bağlllıktır (Budak, 2009: 33). Başka bir ifadeyle çalışanın kurumu ile yakın olma durumu (Balay, 2000: 2), çalıştığı kuruma ait olma duygusudur (Arı, 2003: 3). Örgütsel bağlılık üç boyutta incelenmektedir. Bunlar; duygusal bağhllık: Bireyin hiç kimsenin etkisi altında kalmadan kendi kararıyla ve isteyerek örgütte kalması ve kalmaya da devam etmesi (Bayram, 2005: 132; Polat, 2020: 28), devam bă̆lılı̆̆ı: Örgütten ayrılmanın doğurabileceği maliyet ve bu maliyet karşısında çalışanın örgütte kalmaya devam etmesi davranışı (Acar, 2020: 39) ve normatif bă̆lılık: Çalışanın vazife duygusu ve ahlaki ilkeler nedeniyle örgütten ayrılmaması, aldığı bu kararın ahlaki ilkelere 
uygun olduğunu düşünmesi (Selbi, 2019: 17) şeklinde açıklanabilir. Örgütsel bağl1lık, örgütün kendisine ve örgüt tarafından belirlenen hedeflere uyma, örgüt tarafından oluşturulan değerleri benimseme, örgütün çıkarlarına yönelik eylemlerde bulunma gayretini ifade eder. İşgörenlerin üyesi oldukları örgütü algılama şekline göre örgütsel bağlılık düzeyleri değişebilir, böylelikle işgörenler bazen güçlü duygusal, bazen de çıkarlarına dayalı olarak ihtiyaçlarına göre şekillenebilen bir biçimde örgütsel bağlılık sergileyebilirler. Bu bilgilerden hareketle öğretmenlerin meslektaşları hakkında konuşmaları, örgüt veya çalışanlarla ilgili bilinmeyenlere informal bir şekilde ulaşma çabası içine girmeleri dedikodu şeklinde kendini göstermekte ve bu durum öğretmenlerin örgütsel bağlılıklarını olumlu veya olumsuz yönde etkileyebilmektedir.

En küçük yapılardan biri olan aileden ve en büyük yapilardan biri olan devlete kadar bütün örgütlerde ya kısa ya da uzun süreli kalınır. Yapılan veya yapılacak dedikodular bireyin ileriki yaşantısında karşısına çıktığında, bireyin bu dedikodular karşısında örgüte bağlılığı etkilenir mi? Etkilenmesi durumunda dedikodunun işlevi ne olacaktır? Bu sorular 1şığında yapılan dedikodunun; örgütte nasıl karşılık bulduğu, dedikodunun neden yapıldığı, örgütsel işlevinin ne olduğu, yapılan dedikoduların bağlılığı nasıl etkilediği sorgulandığında ortaya çıkan temel problem dedikodu ve bağlılık ilişkisi olacaktır. Bu bağlamda; araştırmanın problem cümlesi, “Okullarda örgütsel dedikodunun işlevleri ile bağlılık arasındaki ilişki ne düzeydedir?" şeklinde ifade edilebilir.

$\mathrm{Bu}$ araştırmanın temel amacı öğretmenlere göre okullarda örgütsel dedikodunun işlevleri ile bağlılık arasındaki ilişkiyi incelemektir. Bu amaçla aşağıda yer verilen sorulara cevap aranmıştır;

1. Öğretmen görüşlerine göre okullarda örgütsel dedikodunun işlevleri ile bağl1lık arasında anlamlı bir ilişki var mıdır?

2. Öğretmen görüşlerine göre okullarda örgütsel dedikodu örgütsel bağlılığın anlamlı bir yordayıcısı midır?

\section{YÖNTEM}

\section{Araştırma Modeli}

"Bir olay veya konu hakkında katılımcıların düşüncelerini ya da ilgi, beceri, yetenek, tutum vb. özelliklerinin belirlendiği genellikle diğer araştırmalara göre daha büyük örneklemler üzerinde yapılan araştırmalar" biçiminde belirtilen ve nicel araştırma tekniklerinden biri olan tarama yöntemiyle gerçekleştirilen bu çalışmada okullarda görev yapmakta olan öğretmenlerin örgütsel dedikodu ve bağlılıkları arasındaki ilişkiyi belirlemek amacıyla yapıldığından ilişkisel tarama modeli kullanılmıştır. İlişkisel tarama iki veya daha çok değişken arasındaki birlikte değişimin varlığını ve derecesini belirlemeyi amaçlar (Karasar, 2018: 82). Bununla beraber tarama araştırmalarında temel amaçlarından biri değişkenler arasındaki ilişkileri test etmektir. Örneklem grubu arasındaki ilişkilerden yola çıkılarak evrenle ilgili çıkarımlarda bulunulur (Gay, Mills ve Airasian, 2006). Böylelikle okullardaki örgütsel dedikodu ve örgütsel bağlılıkları arasında ilişki de belirlenmeye çalışılmıştır.

\section{Evren ve Örneklem}

Araştırmanın evrenini 2020-2021 eğitim-öğretim yılında Siirt'te kamu okullarında görev yapan 5325 öğretmen oluşturmaktadır. Araştırmanın örneklemini ise Siirt'te kamu okullarında görev yapan ve basit tesadüfi örnekleme yöntemiyle belirlenen 384 öğretmen oluşturmaktadır. Evrenin tamamina zaman, enerji ve maliyet gibi sebeplerden ötürü ulaşılmanın zor olduğu düşünüldüğünden, araştırma evreninden seçilen örneklem üzerinden gerçekleştirilmiştir. Örneklem büyüklüğünün belirlenmesi işleminde ise evreni oluşturan varlıkların toplam sayısının 
bilindiği durumlarda Büyüköztürk, vd. (2018) "Süreksiz değişkenlerde farklı sapma miktarları için uygun örneklem büyüklükleri örneklem tablosu"ndan yararlanılmıştır. Bu kapsamda 5325 öğretmenden oluşan evrenin $\alpha=0.05$ anlamlılık ve \%95 kesinlik düzeyinde minimum 370 öğretmen temsil edebilecek iken 384 öğretmen araştırmanın örneklemini oluşturmuştur. Araştırmada yer alan öğretmenlerin kişisel değişkenlerinin (cinsiyet, yaş, medeni durum, okul kademesi, öğrenim durumu, görev, kıdem, öğretmen sayısı ve sosyal medya kullanım düzeyi) dağılımlarına ilişkin yüzde ve frekans bilgileri Tablo 1' de verilmiştir.

Tablo 1. Öğretmenlerin Kişisel Bilgilerine Göre Dağılımları

\begin{tabular}{|c|c|c|c|}
\hline Kişisel Özellikler & & Frekans(n) & Yüzde(\%) \\
\hline \multirow{2}{*}{ Cinsiyet } & Kadın & 205 & 53.4 \\
\hline & Erkek & 179 & 46.6 \\
\hline \multirow{5}{*}{ Yaş } & $22-26$ & 86 & 22.4 \\
\hline & $27-31$ & 140 & 36.5 \\
\hline & $32-36$ & 88 & 22.9 \\
\hline & $37-41$ & 50 & 13.0 \\
\hline & 42 yaş ve üzeri & 20 & 5.2 \\
\hline \multirow{2}{*}{ Medeni Durum } & Bekâr & 169 & 44.0 \\
\hline & Evli & 215 & 56.0 \\
\hline \multirow{4}{*}{ Okul Kademesi } & Okulöncesi & 70 & 18.2 \\
\hline & İlkokul & 114 & 29.7 \\
\hline & Ortaokul & 121 & 31.5 \\
\hline & Lise & 79 & 20.6 \\
\hline \multirow{2}{*}{ Öğrenim Durumu } & Lisans & 333 & 86.7 \\
\hline & Lisansüstü & 51 & 13.3 \\
\hline \multirow{2}{*}{ Görevi } & Öğretmen & 313 & 81.5 \\
\hline & Yönetici & 71 & 18.5 \\
\hline \multirow{4}{*}{ Mesleki Kıdem } & $1-5$ y1l & 234 & 60.9 \\
\hline & 6-10 y1l & 67 & 17.4 \\
\hline & $11-20$ y1l & 68 & 17.7 \\
\hline & 21 ve üzeri yıl & 15 & 3.9 \\
\hline \multirow{3}{*}{$\begin{array}{l}\text { Okulda Çalışan Öğretmen Sayısı } \\
\text { (Okul Büyüklüğü) }\end{array}$} & 28 ve aşağ1(Küçük okul) & 285 & 74.2 \\
\hline & $\begin{array}{l}\text { 29-39 arası(Orta büyüklükteki } \\
\text { okul) }\end{array}$ & 80 & 20.8 \\
\hline & 40 ve üzeri(Büyük okul) & 19 & 4.9 \\
\hline \multirow{4}{*}{ Sosyal Medya Kullanım Sıklığı } & Kullanmam & 17 & 4.4 \\
\hline & Bazen kullanırım & 194 & 50.5 \\
\hline & Çok kullanırım & 173 & 45.1 \\
\hline & Toplam & 384 & 100.0 \\
\hline
\end{tabular}

Tablo 1' de görülen örneklem grubunun kişisel bilgileri incelendiğinde, katılımcıların cinsiyetleri bakımından \%53,4'ünün (205 kişi) kadınlardan, \%46,6'sının ise (179 kişi) erkeklerden oluştuğu görülmektedir. Öğretmenlerin yaşları bakımından \%22,4'ünün (86 kişi) 22-26 yaş arasında, \%36,5'inin (140 kişi) 27-31 yaş arasında, \%22,9'unun (88 kişi) 32-36 yaş arasında, \%13'ünün (50 kişi) 37-41 yaş arasında ve \%5,2'sinin (20 kişi) 42 yaş ve üzeri olduğu saptanmıştır. Öğretmenlerin medeni durumları bakımından \%44'ünün (169 kişi) bekâr ve \%56'sının (215 kişi) evli oldukları görülmektedir. Öğretmenlerin çalıştıkları okul kademesi bakımından \%18,2'sinin (70 kişi) 
okulöncesi kademesinde, \%29,7'sinin (114 kişi) ilkokul kademesinde, \%31,5'inin (121 kişi) ortaokul kademesinde ve \%20,6'sının lise kademesinde çalıştıkları saptanmıştır. Öğretmenlerin öğrenim durumları bakımından \%86,7'sinin (333 kişi) lisans mezunu ve \%13,3'ünün (51 kişi) lisansüstü mezunu oldukları görülmektedir. Katılımcıların okuldaki görevleri bakımından \%81,5'inin (313 kişi) öğretmen ve \%18,5'inin (71 kişi) yönetici olarak görev yatıkları saptanmıştır. Öğretmenlerin mesleki kıdem bakımından \%60,9'unun (234 kişi)1-5 yıl arasında, \%17,4'ünün (67 kişi) 6-10 yıl arasında, \%17,7' $\operatorname{sinin}$ (68 kişi) 11-20 yıl arasında ve \%3,9'unun (15 kişi) 21 ve üzeri y1l oldukları saptanmıştır. Öğretmenlerin görev yaptıkları okul büyüklüğü bakımından \%74,2'sinin (285 kişi) küçük okullarda, \%20,8'inin (80 kişi) orta büyüklükteki okullarda ve \%4,9'unun (19 kişi) büyük okullarda görev yaptıkları görülmektedir. Öğretmenlerin sosyal medya kullanım sıklığı bakımından \%4,4'ünün (17 kişi) sosyal medyayı kullanmamakta, \%50,5'inin (194 kişi) bazen kullanmakta ve \%45,1'inin (173 kişi) ise çok kullanmakta olduğu görülmektedir.

Araştırmada kullanılan bağımsız değişkenlerden öğretmenlerin çalıştıkları "okul büyüklüğ̈̈" değişkeninde yer alan okul büyüklüğünün belirlemesinde Jones'in (1997) öne sürdüğü ölçütler kullanılmıştır. Bu ölçütlere göre 28 ve daha az öğretmenin görev yaptığ1 okullar "küçük okul", 2939 arası öğretmenin görev yaptığı okullar "orta büyüklükteki okul" ve 40 ve üzeri öğretmenin görev yaptığı okullar ise "büyük okul” olarak gruplandırılmıştır (Aktaran; Han, 2019: 122).

\section{Veri Toplama Araçları}

Bu araştırmada "Kişisel Bilgi Formu”, “Örgütsel Dedikodu Ölçeği” ve “Örgütsel Bağlılık Ölçeği” olmak üzere üç bölümden oluşan bir veri toplama aracı kullanılmıştır.

\section{Veri Toplama Süreci}

Ölçeklerin toplanmasında yeterli sayıya ulaşamama ihtimali ve öğretmenlere ulaşmadaki zorluklar sebebiyle ölçekler öğretmenlere uygulanmak üzere Google Forms üzerinden oluşturulmuştur. Yüklemesi yapılan ölçeklerin 2020-2021 eğitim öğretim yılı içinde Siirt İl Milli Eğitim Müdürlüğü'ne bağlı okullarda görev yapan öğretmenler tarafından çevrimiçi doldurmaları sağlanmıştır. Ankete katılım gösteren öğretmenlere araştırmanın amacı ve kişisel bilgilerin saklı tutulacağına dair bilgi verilmiştir. Ölçme araçları uygulandıktan sonra 384 ölçek analiz edilmeye uygun bulunmuştur.

Etik Kurul İzni: Bu çalışma için etik kurul izni Siirt Üniversitesi Etik Kurulu'nun 08/03/2021 tarihli ve 70 numaralı kararı ile alınmıştır.

\section{Verilerin Analizi}

Araştırma kapsamında elde edilen veriler SPSS 23.0 istatistik paket programı kullanılarak analiz edilmiştir. Araştırmaya katılan öğretmenlerin kişisel bilgilerine (cinsiyet, yaş, medeni durum, çalışılan okul kademesi, öğrenim durumu, okuldaki görevi, mesleki kıdem, okul büyüklüğü, sosyal medya kullanım sıklığı) ilişkin verilerin frekans (f) ve yüzde (\%) dağılımları hesaplanmıştır. Ayrıca ölçeklerdeki her bir maddenin ve boyutlarının aritmetik ortalama $(\bar{x})$ ve standart sapma (s.s) değerleri hesaplandıktan sonra ölçeklerin ilgili maddelerine ve boyutlarına ilişkin betimleme de yapılmıştır. Ayrıca normallik varsayımları incelendiğinde örgütsel dedikodu ve örgütsel bağlılık toplamında ve alt boyutlarında çarpıklık ve basıklık katsayılarının $\pm 1,5$ sınırları içerisinde olması ortalama ve medyanın yakın olması sonucu (Tabachnick ve Fidell, 2013), \pm 2 arasında değerler alması (George ve Mallery, 2010'dan aktaran: Han, 2019: 126) ayrıca örneklem hacminin yeterli sayıda olmasından dolayı verilerin dağılımın normal olduğu varsayımı ile parametrik analizler yapılmıştır. Bağımsız değişkenlerde mesleki kıdem, yaş ve sosyal medya kullanım sıklığı 
değişkenlerinde alt gruplardaki katılımcı sayılarının 30'a inmesinden ötürü veri birleştirme yoluna gidilmiştir. Mesleki kıdemde 21 yıl ve üzeri 11-20 yıl arası ile birleştirilerek 11 yıl ve üzerine dönüştürülmüştür. Bunun yanında yaş değişkeninde 42 yaş ve üzeri 37-41 yaş ile birleştirilerek 37 yaş ve üzerine dönüştürülmüştür. Sosyal medya kullanımında ise hiç kullanmam ile bazen kullanırım alt grupları birleştirilmiştir.

Örneklem grubunu oluşturan öğretmenlerin örgütsel dedikodu ve örgütsel bağlılıkları arasındaki ilişkinin derecesini belirlemek amacıyla Pearson momentler korelasyon ( $r$ ) analiz tekniği kullanılmıştır. Araştırmada yer alan ölçekler ve alt boyutlarının birbiri arasındaki ilişki için Pearson korelasyon katsayısı kullanılmış olup alt boyutların birbiri arasındaki korelasyon puanları 0.00- 0.30 arasında olması "düşük", 0.30-0.70 arasında olması "orta" ve 0.70-1.00 arasında olması ise "yüksek" ilişkiyi göstermektedir (Büyüköztürk ve diğerleri, 2018: 113).

Öğretmen görüşlerine göre örgütsel dedikodu işlevlerinin örgütsel bağlılıkları üzerindeki etkisinin belirlenebilmesi için çoklu regresyon analiz tekniği kullanılmıştır. Son olarak araştırmaya ait hipotezler $\mathrm{p}<.05$ anlamlılık düzeyinde test edilmiştir.

\section{BULGULAR}

Araştırmanın bu bölümünde, araştırmaya katılan öğretmenlerden elde edilen verilerin yöntem bölümünde açıklanan şekilde analiz edilmesi sonucunda elde edilen bulgular bulunmaktadır.

\section{Öğretmen Görüşlerine Göre Örgütsel Dedikodu İle Örgütsel Bağlılık Arasındaki İlişkiye Yönelik Bulgular ve Yorumlar}

Öğretmenlerin görüşlerine göre okullarda örgütsel dedikodu ile örgütsel bağl1lık arasında anlamlı bir ilişki olup olmadığını belirlemek için öğretmenlerin örgütsel dedikodu ve bağlılığa ilişkin görüşlerinin boyut bazında korelasyonları hesaplanmıştır. Öğretmenlerin örgütsel dedikodu ile örgütsel bağlılığa ilişkin görüşleri arasındaki ilişkiyi belirlemek için basit doğrusal Korelasyon Analizi yapılmıştır. Korelasyon analizi sonucunda yapılan karşılaştırmalar Tablo 2' de verilmiştir.

Tablo 2. Öğretmen Görüşlerine Göre Örgütsel Dedikodu İle Örgütsel Bağlılık Arasındaki Korelasyona İlişkin Bulgular

\begin{tabular}{|c|c|c|c|c|c|c|c|}
\hline & 1 & 2 & 3 & 4 & 5 & 6 & 7 \\
\hline Haberdar Olma & 1 & & & & & & \\
\hline İlişkileri Geliştirme & $.492^{* *}$ & 1 & & & & & \\
\hline Örgütsel Zarar & -.043 & $-.419^{* *}$ & 1 & & & & \\
\hline Duygusal Bağlılık & $-.281^{* *}$ & -.059 & -.053 & 1 & & & \\
\hline Devam Bağll1lı̆ğ & $-.106^{*}$ & -.050 & $.110^{*}$ & $.536^{* *}$ & 1 & & \\
\hline Normatif Bağl1l1k & $-.181^{* *}$ & -.060 & .068 & $.554^{* *}$ & $.639^{* *}$ & 1 & \\
\hline Toplam Bağlılık & $-.226^{* *}$ & -.067 & .048 & $.826^{* *}$ & $.847^{* *}$ & $.868^{* *}$ & 1 \\
\hline
\end{tabular}

Tablo 2' de görüldüğü gibi dedikodunun haberdar olma boyutu ile bağlılı̆̆ın duygusal bağhllık boyutu arasında (r=--281; p<.01) negatif yönde, düşük düzeyde, anlamlı bir ilişki; devam bağgllı̆̆ı boyutu arasında (r=-,106; p<.05) negatif yönde, düşük düzeyde, anlamlı bir ilişki; normatif bağhllık boyutu arasında ( $\mathrm{r}=-, 181 ; \mathrm{p}<.01)$ negatif yönde, düşük düzeyde, anlamlı bir ilişki; örgütsel bağlllı̆̆ın 
toplamında (r=--226; $\mathrm{p}<.01)$ negatif yönde, düşük düzeyde, anlamlı bir ilişki bulunmuştur.

Dedikodunun ilişkileri geliştirme boyutu ile bağlılı̆̆ın duygusal bağhllık boyutu arasında (r=-,059) negatif yönde, düşük düzeyde; devam bă̆gllı̆̆ı boyutu arasında (r=-,050) negatif yönde, düşük düzeyde; normatif bağlllık boyutu arasında ( $\mathrm{r}=-.060)$ negatif yönde, düşük düzeyde; örgütsel bağhllı̆̆ın toplamında ( $(\mathrm{r}=-$,067) negatif yönde, düşük düzeyde, istatiski açıdan anlamlı olmayan bir ilişki bulunmuştur.

Dedikodunun örgütsel zarar boyutu ile bağlılığın devam bağhllı̆̆ı boyutu arasında $(\mathrm{r}=, 110 ; \mathrm{p}<.05)$ pozitif yönde, düşük düzeyde, anlamlı bir ilişki; duygusal bağhllık boyutu arasında (r=-,053) negatif yönde, düşük düzeyde; normatif bağglllk boyutu arasında $(\mathrm{r}=, 068)$ pozitif yönde, düşük düzeyde; örgütsel bağhllı̆̆ın toplamında $(\mathrm{r}=, 048)$ pozitif yönde, düşük düzeyde, istatiski açıdan anlamlı olmayan bir ilişki bulunmuştur.

\section{Öğretmen Görüşlerine Göre Örgütsel Dedikodunun Örgütsel Bağlılı̆ğ Yordamasına İlişkin Bulgular}

Öğretmenlerin örgütsel dedikodunun işlevlerine yönelik görüşlerinin (haberdar olma, ilişkileri geliştirme ve örgütsel zarar boyutları) örgütsel bağlılık alt boyutlarından duygusal bağlılığa olan etkisini belirlemek için çoklu regresyon analizi sonuçları Tablo 3 'te verilmiştir.

Tablo 3. Örgütsel Dedikodunun Örgütsel Bağlılık Alt Boyutu Olan Duygusal Bağlılığa İlişkin Çoklu Regresyon Analiz Sonuçları

\begin{tabular}{lllllll}
\hline \multirow{2}{*}{ Değişkenler } & & & & & \\
& & B & Std. Ht. & $\boldsymbol{\beta}$ & $\boldsymbol{t}$ & $\boldsymbol{p}$ \\
\hline \multirow{3}{*}{ Bağımsıżz Değişken } & 4.260 & .282 & & 15.089 & $\mathbf{. 0 0 0}^{*}$ \\
& Haberdar Olma & -.306 & .054 & -.326 & -5.664 & $\mathbf{. 0 0 0}^{*}$ \\
& İlişkileri Geliştirme & .095 & .068 & .089 & 1.404 & $\mathbf{. 1 6 1}$ \\
& Örgütsel Zarar & -.033 & .061 & -.030 & -.543 & .587 \\
\hline
\end{tabular}

* $\mathrm{p}<.05$ Bağımlı Değişken: Duygusal Bağlılık

$\mathbf{R}=, 296 \quad \mathbf{R}^{2}=, 088 \quad \mathbf{F}(3-380)=12,200 \quad \mathbf{p}=.000$

Duygusal bağlılık düzeyi üzerinde etkisi olduğu düşünülen, haberdar olma, ilişkileri geliştirme ve örgütsel zarar gibi değişkenlerin, duygusal bağlılığı ne şekilde yordadığını ortaya koymaya yönelik olarak yapılan çoklu doğrusal regresyon analizi sonucunda, haberdar olma, ilişkileri geliştirme ve örgütsel zarar değişkenleri birlikte, duygusal bağlılık ile anlamlı bir ilişki ( $R=, 296$, $\left.\mathrm{R}^{2}=, 088\right)$ sergilemişlerdir $(\mathrm{F}(3-380)=12,200, \mathrm{p}<0,01)$. Söz konusu üç değişken, duygusal bağlılık düzeyindeki değişimin \% 8'ini açıklamaktadır. Standartlaştırılmış regresyon katsayılarına göre, yordayıcı değişkenlerin, duygusal bağlılık düzeyi üzerindeki göreli önem sırası, haberdar olma ( $\beta=-, 326)$ ilişkileri geliştirme $(\beta=, 089)$, ve $(\beta=-, 030)$ örgütsel zarardır. Regresyon katsayılarının anlamlılık testleri göz önüne alındı̆̆ında, yordayıcı değişkenlerden sadece haberdar olma $(\mathrm{p}<0,01)$ değişkeninin, duygusal bağlılık üzerinde anlamlı yordayıcı olduğu görülmektedir. Regresyon analizi sonuçlarına göre, duygusal bağlılığı yordayan regresyon denklemi şu şekildedir:

Duygusal bağl1lık= (-,306 X Haberdar Olma) + (,095 X İlişkileri Geliştirme $)+(-, 033$ X Örgütsel Zarar) $+4,260$

Öğretmenlerin örgütsel dedikodunun işlevlerine yönelik görüşlerinin (haberdar olma, ilişkileri geliştirme ve örgütsel zarar boyutları) örgütsel bağlılık alt boyutlarından devam bağlılığına olan etkisini belirlemek için çoklu regresyon analizi sonuçları Tablo $4^{\prime}$ te verilmiştir. 
Tablo 4. Örgütsel Dedikodunun Örgütsel Bağlılık Alt Boyutu Olan Devam Bağlılığına İlişkin Çoklu Regresyon Analiz Sonuçları

\begin{tabular}{lllllll} 
Değişkenler & & B & Std. Ht. & $\boldsymbol{\beta}$ & $\boldsymbol{t}$ & $\boldsymbol{p}$ \\
\hline \multirow{4}{*}{ Bağımmsız Değişken } & Sabit & 2.833 & .271 & & 10.450 & $\mathbf{. 0 0 0 ^ { * }}$ \\
& Haberdar Olma & -.120 & .052 & -.137 & -2.303 & $\mathbf{. 0 2 2}^{*}$ \\
& İlişkileri Geliştirme & .074 & .065 & .074 & 1.130 & $\mathbf{. 2 5 9}$ \\
& Örgütsel Zarar & .138 & .058 & .136 & 2.378 & $\mathbf{. 0 1 8 ^ { * }}$ \\
\hline
\end{tabular}

*p $<.05$ Bağımlı Değişken: Devam Bağlılığı

$\mathbf{R}=, 161 \quad \mathbf{R}^{2}=, 026 \quad \mathbf{F}(3-380)=3,355 \quad \mathbf{p}=.019$

Devam bağlılığı düzeyi üzerinde etkisi olduğu düşünülen, haberdar olma, ilişkileri geliştirme ve örgütsel zarar gibi değişkenlerin, devam bağlılığı ne şekilde yordadığını ortaya koymaya yönelik olarak yapılan çoklu doğrusal regresyon analizi sonucunda, haberdar olma, ilişkileri geliştirme ve örgütsel zarar değişkenleri birlikte, devam bağlılığı ile anlamlı bir ilişki $\left(R=, 161, R^{2}=, 026\right)$ sergilemişlerdir $(F(3-380)=3,355, p<0,05)$. Söz konusu üç değişken, birlikte, devam bağl1lı̆̆1 düzeyindeki değişimin \%2'sini açıklamaktadır. Standartlaştırılmış regresyon katsayılarına göre, yordayıcı değişkenlerin, devam bağlılığı düzeyi üzerindeki göreli önem sırası, haberdar olma ( $\beta=-$ ,137), örgütsel zarar $(\beta=, 136)$ ve ilişkileri geliştirmedir. $(\beta=, 074)$. Regresyon katsayılarının anlamlılık testleri göz önüne alındığında, yordayıcı değişkenlerden sadece haberdar olma $(p<0,05)$ ve örgütsel zarar $(p<0,05)$ değişkeninin, devam bağlılığı üzerinde anlamlı yordayıcı olduğu görülmektedir. Regresyon analizi sonuçlarına göre, devam bağlılığı yordayan regresyon denklemi şu şekildedir:

Devam Bağlılığı= (-,120 X Haberdar Olma) + (,074 X İlişkileri Geliştirme) + (,138 X Örgütsel Zarar $)+$ 2,833

Öğretmenlerin örgütsel dedikodunun işlevlerine yönelik görüşlerinin (haberdar olma, ilişkileri geliştirme ve örgütsel zarar boyutları) örgütsel bağlılık alt boyutlarından normatif bağlılığa olan etkisini belirlemek için çoklu regresyon analizi sonuçları Tablo 5'te verilmiştir.

Tablo 5. Örgütsel Dedikodunun Örgütsel Bağlılık Alt Boyutu Olan Normatif Bağlılığa İlişkin Çoklu Regresyon Analiz Sonuçları

\begin{tabular}{lllllll} 
Değişkenler & & B & Std. Ht. & $\boldsymbol{\beta}$ & $\boldsymbol{t}$ & $\boldsymbol{p}$ \\
\hline \multirow{4}{*}{ Bağımmsız Değişken } & Sabit & 3.021 & .296 & & 10.196 & $\mathbf{. 0 0 0 ^ { * }}$ \\
& Haberdar Olma & -.212 & .057 & -.221 & -3.742 & $\mathbf{. 0 0 0}^{*}$ \\
& İlişkileri Geliştirme & .097 & .071 & .089 & 1.367 & $\mathbf{. 1 7 2}$ \\
& Örgütsel Zarar & .108 & .064 & .096 & 1.699 & $\mathbf{. 0 9 0}$ \\
\hline
\end{tabular}

" $\mathrm{p}<.05$ Bağımlı Değişken: Normatif Bağlılık

$\mathbf{R}=, 203 \quad \mathbf{R}^{2}=, 041 \quad \mathbf{F}(3-380)=5,444 \quad \mathbf{p}=.001$

Normatif bağlılık düzeyi üzerinde etkisi olduğu düşünülen, haberdar olma, ilişkileri geliştirme ve örgütsel zarar gibi değişkenlerin, normatif bağlılığı ne şekilde yordadığını ortaya koymaya yönelik olarak yapılan çoklu doğrusal regresyon analizi sonucunda, haberdar olma, ilişkileri geliştirme ve örgütsel zarar değişkenleri birlikte, normatif bağlılık ile anlamlı bir ilişki $\left(R=, 203, R^{2}=, 041\right)$ sergilemişlerdir $(\mathrm{F}(3-380)=5,444, \mathrm{p}<0,01)$. Söz konusu üç değişken, birlikte, normatif bağlılık düzeyindeki değişimin \%4'ünü açılamaktadır. Standartlaştırılmış regresyon katsayılarına göre, 
yordayıcı değişkenlerin, normatif bağlılık düzeyi üzerindeki göreli önem sırası, haberdar olma $(\beta=-, 221)$, örgütsel zarar $(\beta=, 096)$, ilişkileri geliştirmedir. $(\beta=, 089)$ Regresyon katsayılarının anlamlılık testleri göz önüne alındığında, yordayıcı değişkenlerden sadece haberdar olma $(\mathrm{p}<0,01)$ değişkeninin, normatif bağlılık üzerinde anlamlı yordayıcı olduğu görülmektedir. Regresyon analizi sonuçlarına göre, normatif bağlllı̆̆ yordayan regresyon denklemi şu şekildedir:

Normatif Bağlılık= (-,212 X Haberdar Olma) + (,097 X İlişkileri Geliştirme $)+(, 108$ X Örgütsel Zarar $)$ $+3,021$

Öğretmenlerin örgütsel dedikodunun işlevlerine yönelik görüşlerinin (haberdar olma, ilişkileri geliştirme ve örgütsel zarar boyutları) toplam örgütsel bağlılığa olan etkisini belirlemek için çoklu regresyon analizi sonuçları Tablo 6 'da verilmiştir.

Tablo 6. Örgütsel Dedikodu İşlevlerinin Örgütsel Bağlılığın Toplamına İlişkin Çoklu Regresyon Analiz Sonuçları

\begin{tabular}{lllllll} 
Değişkenler & & B & Std. Ht. & $\boldsymbol{\beta}$ & $\boldsymbol{t}$ & $\boldsymbol{p}$ \\
\hline \multirow{3}{*}{ Bağımsız Değişken } & Sabit & 3.372 & .239 & & 14.096 & $\mathbf{. 0 0 0 *}$ \\
& Haberdar Olma & -.213 & .046 & -.271 & -4.644 & $\mathbf{. 0 0 0}^{*}$ \\
& İlişkileri Geliştirme & .089 & .057 & .099 & 1.544 & $\mathbf{. 1 2 3}$ \\
& Örgütsel Zarar & .071 & .051 & .078 & 1.386 & $\mathbf{. 1 6 7}$ \\
\hline
\end{tabular}

"p < .05 Bağımlı Değişken: Toplam Örgütsel Bağl1lık

$\mathbf{R}=, 242 \quad \mathbf{R}^{2}=, 058 \quad \mathbf{F}(3-380)=7,853 \mathbf{p}=.000$

Toplam Örgütsel Bağl1lık düzeyi üzerinde etkisi olduğu düşünülen, haberdar olma, ilişkileri geliştirme ve örgütsel zarar gibi değişkenlerin, örgütsel bağlılı̆̆ın toplamını ne şekilde yordadığını ortaya koymaya yönelik olarak yapılan çoklu doğrusal regresyon analizi sonucunda, haberdar olma, ilişkileri geliştirme ve örgütsel zarar değişkenleri birlikte, örgütsel bağlılığın toplamı ile anlamlı bir ilişki $\left(R=, 242, R^{2}=, 058\right)$ sergilemişlerdir ( $\left.F(3-380)=7,853, p<0,01\right)$. Söz konusu üç değişken, birlikte, toplam örgütsel bağlılık düzeyindeki değişimin \%5'ini açılamaktadır. Standartlaştırılmış regresyon katsayılarına göre, yordayıcı değişkenlerin, toplam örgütsel bağlılık düzeyi üzerindeki göreli önem sırası, haberdar olma $(\beta=-, 271)$, ilişkileri geliştirme $(\beta=, 099)$ ve örgütsel zarardır. $(\beta=, 078)$ Regresyon katsayılarının anlamlılık testleri göz önüne alındığında, yordayıcı değişkenlerden sadece haberdar olma $(p<0,01)$ değişkeninin, toplam örgütsel bağlılık üzerinde anlamlı yordayıcı olduğu görülmektedir. Regresyon analizi sonuçlarına göre, örgütsel bağl1lı̆̆ın toplamını yordayan regresyon denklemi şu şekildedir:

Toplam Örgütsel Bağlılık= (-,213 X Haberdar Olma $)+(, 089$ X İlişkileri Geliştirme $)+(, 071$ X Örgütsel Zarar) $+3,372$

\section{TARTIŞMA, SONUÇ ve ÖNERİLER}

Araştırmanın bu bölümünde, öğretmenlerin örgütsel dedikodunun işlevlerine yönelik görüşleri ve örgütsel bağlılık düzeylerine ilişkin yapılan analizler neticesinde elde edilen bulguların sonuçları sunulmuş ve bu sonuçlar tartışılmıştır.

\section{Öğretmen Görüşlerine Göre Örgütsel Dedikodu ile Bağlılık Arasındaki İlişkiye Yönelik Sonuç ve Tartışma}

Örgütsel dedikodu ve bağlılık arasındaki ilişkileri açığa çıkarmak için yapılan analiz sonuçlarında, 
örgütsel dedikodu ve bağlılık arasında anlamlı ilişkiler ortaya çıkarılmıştır. Buna göre dedikodunun haberdar olma boyutu ile bağlılığın duygusal bağhllık boyutu arasında negatif yönde, düşük düzeyde, anlamlı bir ilişki; devam bağhllı̆̆ı boyutu arasında negatif yönde, düşük düzeyde, anlamlı bir ilişki; normatif bağhlık boyutu arasında negatif yönde, düşük düzeyde, anlamlı bir ilişki; örgütsel bağlllığın toplamında negatif yönde, düşük düzeyde, anlamlı bir ilişki bulunmuştur. Dedikodunun ilişkileri geliştirme boyutu ile bağlılığın duygusal bağhllık boyutu arasında negatif yönde, düşük düzeyde; devam bağhllığı boyutu arasında negatif yönde, düşük düzeyde; normatif bağhllık boyutu arasında negatif yönde, düşük düzeyde; örgütsel bağhllı̆̆ın toplamında negatif yönde, düşük düzeyde, istatiski açıdan anlamlı olmayan bir ilişki bulunmuştur. Dedikodunun örgütsel zarar boyutu ile bağlılığın devam bağglı̆ğ̊ boyutu arasında pozitif yönde, düşük düzeyde, anlamlı bir ilişki; duygusal bağhllık boyutu arasında negatif yönde, düşük düzeyde; normatif bă̆gllık boyutu arasında $(\mathrm{r}=, 068)$ pozitif yönde, düşük düzeyde; örgütsel bağlılı̆̆ın toplamında pozitif yönde, düşük düzeyde, istatiski açıdan anlamlı olmayan bir ilişki bulunmuştur.

Görüldüğü üzere, öğretmenlerin dedikodunun haberdar olma boyutuna ilişkin görüşleri arttıkça, öğretmenlerin bağlilığın duygusal bağhllık, devam bağgllı̆̆g ve normatif bağhllık boyutlarına ve örgütsel bağ̆llı̆̆ın toplamına yönelik görüşlerini olumsuz yönde etkilemektedir. Buna göre öğretmenler dedikodu yoluyla iletilen haberlerin ve öğrenilen bilgilerin olumsuz yönde olduklarını düşünüyor olabilirler. İletilen haberler kişileri rahatsız edebilecek haberler olduğundan örgütte oluşan dedikodu ortamı örgüte duyulan bağlılı̆̆ı olumsuz yönde etkiliyor olabilir. Bunun yanında öğretmenlerin dedikodunun örgütsel zarar boyutuna ilişkin görüşleri arttıkça, bağlılığın devam bağhlı ı̆g boyutuna ilişkin görüşleri de artmaktadır. Buna göre öğretmenler yapılan dedikoduların örgüte zarar verdiğini düşündüklerinde, örgütte çalışma istekleri azalmakta ve örgütte kalma nedenleri zorunluluktan öteye gitmemektedir. Bu zorunluluğun asıl nedeni de maliyettir denebilir. Buna göre öğretmenlerin düşüncelerine göre dedikodular örgütte çoğunlukla zararlı yönleriyle işlemektedir. Öğretmenlerin dedikodunun işlevlerine yönelik görüşleri arttıkça öğretmenlerin bağlılıkları azalıyorsa, dedikoduların yönetilemediği, bilgi alışverişinin sağlıklı işlemediği veya dedikoduların örgüt yöneticileri tarafından yeterince önemsenmediği söylenebilir.

Alanyazındaki araştırmalarda, dedikodunun olumlu bir hava yaratmak amacıyla kullanıldığında bağlılık duygusunu güçlendireceği (Solmaz, 2004:567), dedikoduların yönetilebildiği takdirde bağlılık duygusunun gelişeceği (Usta ve diğerleri, 2018:8) ileri sürülmektedir. Benzer olarak Kapferer'e göre (1992) bağlılık ve dedikodunun yayılma hızı arasında pozitif bir ilişki vardır. Bunun yanında Merry'e göre (1997) örgüte duyulan bağlllık düzeyinin fazla olduğu yerlerde dedikodular kolayca ortaya çıkarken bağlılık düzeyinin az olduğu yerlerde dedikodular azalarak ortadan kalkar (Aktaran: Özşarlak, 2016: 93). Bu sonuçların aksine Bacaksız ve Yıldırım'ın (2015) sağlık çalışanlarıyla yaptıkları çalışmaya göre dedikodunun bağlılığı azaltarak işten ayrılmalara neden olabildiği sonucuna varılmıştır. Benzer olarak Özdevecioğlu' da (2009) yaptığı çalışmada, Balay'ın (2000) lise öğretmenleriyle yine Çavundurluoğlu'nun (2016) ilköğretim kurumlarında görev yapan öğretmenlerle yaptığı çalışmalarda düşük düzeyde örgütsel bağl1lı̆̆n olumsuz sonuçları arasına dedikodu konulmuştur.

\section{Öğretmen Görüşlerine Göre Örgütsel Dedikodunun Örgütsel Bağlılığı Yordamasına İlişkin Sonuç ve Tartışma}

Örgütsel bağlılığın duygusal bağlılık alt boyutunu örgütsel dedikodunun haberdar olma alt boyutu negatif yönde yordarken ilişkileri geliştirme ve örgütsel zarar alt boyutlarının duygusal bağlılık alt boyutunun yordamadığı ortaya çıkmıştır. Buna göre öğretmenler meslektaşları hakkında bilgi edinme sürecinde dedikoduyu kullandıklarında öğretmenlerin örgüte duydukları 
bağlılık düzeyi azalır ve öğretmenler örgütün amaçları dışında hareket etmeye başlayabilir.

Örgütsel bağlılığın devam bağlılığı alt boyutunu örgütsel dedikodunun haberdar olma alt boyutu negatif yönde ve örgütsel zarar alt boyutu ise pozitif yönde yordamaktadır. Bunun yanında ilişkileri geliştirme alt boyutu devam bağlılığ göre öğretmenler bilgi edinme amacıyla dedikodu yaptıklarında onların örgüte duydukları devam bağlılığı azalmakta, dedikodu örgüte zarar vermeye başladığında ise öğretmenlerin örgüte duydukları devam bağlılığı artmaktadır. Dolayısıyla okullarda dedikodular arttıkça öğretmenlerin okula duydukları bağlılık duygusu istekleri dışına çıkmakta, öğretmenler örgüte ihtiyaçları nedeniyle bağlanmak zorunda olduklarını düşünürler denilebilir.

Örgütsel bağlılı̆̆ın normatif bağl1lık alt boyutunu örgütsel dedikodunun haberdar olma alt boyutu negatif yönde yordarken ilişkileri geliştirme ve örgütsel zarar alt boyutlarının normatif bağlılık alt boyutunun yordamadığı ortaya çıkmıştır. Buna göre öğretmenler örgütleri veya iş arkadaşları hakkında bilgi edinme amacıyla yaptıkları dedikodu onların örgüte duydukları sadakat duygusunun körelmesine neden olabilir böylece öğretmenlerin örgüte duydukları bağlılık azalabilir.

Yapılan alanyazın taramasında öğretmen görüşlerine göre örgütsel dedikodu işlevleri ile örgütsel bağlılık algılarının yordanmasına ilişkin yapılan herhangi bir araştırmaya rastlanılmaması nedeniyle araştırmanın bu sonucuna yönelik benzer ya da farklı herhangi bir sonuca ulaşılamamıştır. Ancak araştırmanın sonucuna benzer olarak Bahar (2016) dedikoduların, bireyler ve örgütler arasındaki bağlılığa zarar vererek düşmanlığı büyüttüğünü söyler (Aktaran: Han, 2020:2331). Bunun yanında Kapferer' da (1992) dedikodunun yayılma hızı ile bağlılık arasında pozitif bir ilişki olduğunu ileri sürmektedir.

Sonuç olarak öğretmen görüşlerine göre örgütsel dedikodu ve örgütsel bağlılık incelendiğinde, öğretmenlerin dedikodunun örgüte zarar verdiğini, meslektaşlarıyla aralarına mesafe koymalarına neden olduğunu, örgüte duydukları bağlılıklarını olumsuz yönde etkilediğini düşünmektedirler. Örgütsel dedikodunun haberdar olma ve ilişkileri geliştirme alt boyutlarında örgütlerde olumlu sonuçlar doğurması beklenirken bunların okullarda işlemediği söylenebilir.

\section{Öneriler}

\section{Uygulayıcılara Yönelik Öneriler}

1. Yöneticiler çalıştıkları okullarda bilgi edinme sürecini sağlıklı bir şekilde yürütmeli, öğretmenlere gerekli olan bilgileri formal bir şekilde sunmalıdır. Öğretmenlere ihtiyaç duydukları bilgileri resmi kanallar kullanılarak iletilmesi onların örgüte duydukları bağlılıkları artırabilir.

2. Yöneticiler okullarda oluşan dedikodu ortamını önemsemeli ve bu ortamları örgüt yararına olacak şekilde yönlendirerek öğretmenlerin örgütsel bağlılık düzeylerini artırabilirler.

3. Dedikoduların ortaya çıkması, yönetilmesi, örgütsel zararları ve yönetilebildiği takdirde örgüte sağlayacağ1 yararlarla ve bunların örgütsel bağlllığa ilişkin etkilerine yönelik okul yöneticilerine hizmet içi eğitimler verilmelidir.

\section{Araştırmacılara Yönelik Öneriler}

1. Bu araştırma nicel yöntem ve ölçeklerle gerçekleştirilmiştir. Buna benzer bir araştırma nitel yöntemler kullanılarak yapılabilir.

2. Bu araştırmada kullanılan bağımsız değişkenler dışında; bulunduğunuz okuldaki hizmet yılınız, 
okuldaki çalışma süreniz( haftalık ders saati), sendika üyeliği, kadro durumu(ücretli, sözleşmeli, kadrolu) ve okulda ek ders-kurs-nöbet vb. yapılan dağıtımları adaletli buluyor musunuz? gibi bağımsız değişkenler kullanılabilir.

3. Örgütsel dedikodu ve farklı liderlik stilleri arasındaki ilişkiye bakılabilir.

4. Bu araştırma resmi okullarda yapılmıştır. Yapılacak araştırmalara özel okullarda dâhil edilebilir.

\section{KAYNAKLAR}

Acar, A. (2020). Sınıf öğretmenlerinin tükenmişlik düzeyleri ile örgütsel bağlllıkları arasındaki ilişki. Siirt Üniversitesi Sosyal Bilimler Enstitüsü, Siirt.

Akduru, H. E. ve Semerciöz, F. (2017). Kamu kurumlarında örgütsel dedikodu ve işyeri yalnızlığına dair bir araştırma. Uluslararası Yönetim İktisat ve İşletme Dergisi, 13(5), 106-119.

Allen, N.J. \& Meyer, J.P. (1990). The measurement and antecedents of affective, continuance and normative commitment to the organization. Journal of Occupational Psychology, 63, 1-18.

Arı, G. S. (2003). Yöneticiye duyulan güven örgütsel bağlılığı artırır mı? Gazi Üniversitesi Ticaret Turizm Eğitim Fakültesi Dergisi, 2, 17-36.

Artaç, M. (2017). Dedikodu ve söylentinin işletme verimliliğine etkisi üzerine mersin ilinde hemşireler üzerine bir uygulama. Yüksek Lisans Tezi, Çă̆ Üniversitesi Sosyal Bilimler Enstitüsü, Mersin.

Bacaksız, F. E. ve Yıldırım, A. (2013). Dedikodu ve söylenti tutumu ölçeğinin geliştirilmesi. Anadolu Hemşirelik ve Sağhlk Bilimleri Dergisi, 16(1), 36-42.

Bacaksız, F.E. ve Yıldırım, A. (2015). Dedikodu ve söylentiler: Hastanelerdeki durum ve hemşirelerin tutumları. Să̆lık ve Hemşirelik Yönetimi Dergisi, 2(3), 113-120.

Balay, R. (2000). Özel ve resmi liselerde yönetici ve öğretmenlerin örgütsel bağhllı̆g (Ankara ili örneği). Doktora Tezi, Ankara Üniversitesi Sosyal Bilimler Enstitüsü, Ankara.

Bayram, L. (2005). Yönetimde yeni bir paradigma: Örgütsel bağlılık. Sayıştay Dergisi, 59, 125-139.

Bektaş, M. ve Erdem, R. (2015), Örgütlerde İnformal İletişim Süreci: Kavramsal bir çerçeve. Afyon Kocatepe Üniversitesi İktisadi ve İdari Bilimler Fakültesi Dergisi, 17(1), 125-139.

Bilginoğlu, E. ve Yozgat, U. (2020). Örgütlerde dedikodunun işyeri morali ve çalışma eforu üzerindeki etkisi. İşletme Araştırmaları Dergisi, 12(3), 2592-2610.

Bekteş, E. (2018). Dikizleme kültürü perspektifinden sanal dedikodu. Yüksek Lisans Tezi, Yaşar Üniversitesi Sosyal Bilimler Enstitüsü, İzmir.

Budak, T. (2009). Illköğretim okullarında görev yapan kadrolu ve sözleşmeli öğretmenlerin örgütsel bağlılıkları. Yüksek Lisans Tezi, Sosyal Bilimler Enstitüsü, İstanbul.

Büyüköztürk, Ş., Çakmak, E. K., Akgün, Ö. E., Karadeniz, Ş. ve Demirel, F.(2018), Bilimsel araştırma yöntemleri. Ankara: Pegem Yayıncilık.

Çavundurluoğlu, E. (2016). İlköğretim kurumlarında görev yapan öğretmenlerin örgütsel bağhllık düzeylerinin incelenmesi. Yüksek Lisans Tezi, Gazi Üniversitesi Eğitim Bilimleri Enstitüsü, Ankara.

Dağlı, A., Elçiçek, Z., ve Han, B. (2018). Örgütsel bağlılık ölçeği'nin türkçeye uyarlanması: geçerlik ve güvenirlik çalışması. Elektronik Sosyal Bilimler Dergisi, Güz -2018, 17(68), s.1765-1777.

Danış. M.S. (2015). Dedikodunun sosyolojisi. Yüksek Lisans Tezi, Selçuk Üniversitesi Sosyal Bilimler Enstitüsü, Konya.

Ergen, S. (2015). Öğretmenlerin örgütsel sinizm düzeyleri ile örgütsel bağhllıkları arasındaki ilişki. Yüksek Lisans Tezi, Eğitim Bilimleri Enstitüsü, Ankara.

Ergeneli, A. (2006). Örgüt ve insan, Ankara: Hacettepe Üniversitesi Yayınları. 
Erol, Y. ve Akyüz, M. (2015). Dünyanın en eski medyası: dedikodunun örgüt düzeyindeki işlevleri ve algılanışı: Sağlık örgütlerinde bir alan araştırması. Zeitschrift für die Welt der Türken/Journal of World of Turks, 7(2), 149-166.

Eroğlu, E. (2005). Yöneticilerin dedikodu ve söylentiye yönelik davranış biçimlerinin belirlenmesi arfor taşıma hizmetleri aş'de bir uygulama. Manas Üniversitesi Sosyal Bilimler Dergisi, 7(13), 203-218.

Gay, M. \& Mills, G. E. Airasian (2006). Educational research. New Jesey: Upper Saddle River.

Güçlü, N. (2003). Örgüt kültürü. Gazi Üniversitesi Sosyal Bilimler Dergisi,23(2), 147-159.

Gürbüz, S. (2019). Örgütsel dedikodu ile işyeri yalnızlığı arasındaki ilişki. Yüksek Lisans Tezi, Harran Üniversitesi Sosyal Bilimler Enstitüsü, Şanlıurfa.

Han, B. (2019). Informal iletişim biçimi olarak okullarda söylenti ve dedikodunun öğretmen görüşlerine göre incelenmesi. Doktora Tezi, Dicle Üniversitesi Eğitim Bilimleri Enstitüsü, Diyarbakır.

Han, B. ve Dağlı, A. (2018). Organizational gossip scale: validity and reliability study. Electronic Turkish Studies, 13(27), 829-846.

Kapferer, J. N. (1992). Dünyanın en eski medyası: Dedikodu ve söylenti. (Çev. Işın Gürbüz). İstanbul: İletişim Yayınları.

Karasar, N. (2018). Bilimsel araştırma yöntemleri. Ankara: Nobel Yayıncılık.

Karasu, Y. (2020). İlköğretim kurumlarında çalışan öğretmenlerin örgütsel dedikodu ve örgütsel güven algıları arasındaki ilişki. Yüksek Lisans Tezi, Eğitim Bilimleri Enstitüsü, Malatya.

Kardaş, K. (2019). Sağlık çalışanlarında dedikodu ve söylenti tutumunun iş tatmini üzerindeki etkileri. Yüksek Lisans Tezi, Çanakkale Onsekiz Mart Üniversitesi Sağlık Bilimleri Enstitüsü, Çanakkale.

Leblebici, N. D., Yıldız, H. H. ve Karasoy, A. (2009). Örgütsel yaşamda dedikodunun araçsallığı ve algılanışı. Sosyal Ekonomik Araştırmalar Dergisi, 9(18), 561-574.

Memişoğlu, S.P. (2013). Kuram ve uygulamada eğitim yönetimi. Ankara: Pegem Akademi.

Özdevecioğlu, M. (2003). Algılanan örgütsel destek ile örgütsel bağl1lık arasındaki ilişkilerin belirlenmesine yönelik bir araştırma. Dokuz Eylül Üniversitesi İ.̇̇.B.F. Dergisi, 18(2), 113-130.

Özşarlak, P. (2016). Örgütlerde dedikodu ve söylentilerin ortaya çıkış nedenleri, içerikleri ve etkilerine ilişkin çalışan algılarının değerlendirilmesi ve bir uygulama örneğgi. Yüksek Lisans Tezi, Yaşar Üniversitesi Sosyal Bilimler Enstitüsü, İzmir.

Polat, İ. (2020). Öğretmenlerin karara katılmaları ile örgütsel bağlılıkları arasındaki ilişki: İzmir Örneği. Yüksek Lisans Tezi, Dokuz Eylül Üniversitesi Eğitim Bilimleri Enstitüsü, İzmir.

Selbi, A. (2019). Okul müdürlerinin kullandıklar liderlik stilleri ve örgütsel adalet davranışlarının öğretmenlerin örgütsel bağglllk ve örgütsel yabancllaşmaların yordama derecesi. Yüksek Lisans Tezi, Mersin Üniversitesi Eğitim Bilimleri Enstitüsü, Mersin.

Solmaz, B. (2004). Kurumsal söylenti ve dedikodu Türkiye'deki işletmeler üzerine bir uygulama. Konya: Tablet Kitabevi.

TDK. Türk Dil Kurumu Türkçe Sözlüğü, (2020). http://www.tdk.gov.tr. adresinden 05.12.2020 tarihinde erişilmiştir.

Tabachnick, B. G. \& Fidell, L. S. (2013). Using multivariate statistics. Boston: Pearson.

Tekgöz, A. (2013). Dedikodunun cinsiyeti: kadın kimliğinin yeniden inşasında dedikodunun rolü. Yüksek Lisans Tezi, Frrat Üniversitesi Sosyal Bilimler Enstitüsü, Elazığ.

Usta, M. E., Kaya, A. ve Özyurt, D. (2018). Örgütsel dedikodu yönetimi. Harran Maarif Dergisi, 3(2), 1-13. 
“Okullarda Örgütsel Dedikodu İle Bağl1lık Arasındaki İlişkinin Öğretmen Görüşlerine Göre İncelenmesi" başlıklı çalışmanın yazım sürecinde bilimsel, etik ve alıntı kurallarına uyulmuş; toplanan veriler üzerinde herhangi bir tahrifat yapılmamış, karşılaşılacak tüm etik ihlallerde "Academia Eğitim Araştırmaları Dergisi ve Editörünün" hiçbir sorumluluğunun olmadığı, tüm sorumluluğun yazar(lar)a ait olduğu ve çalışmanın herhangi başka bir akademik yayın ortamına değerlendirme için gönderilmemiş olduğu bu çalışmanın yazar(lar)1 tarafından taahhüt edilmiştir. 